\title{
Modulation of small molecule solubility and protein binding by arginine
}

\author{
TSUTOMU ARAKAWA $^{1}$, MISAO UOZAKI ${ }^{2}$ and A. HAJIME KOYAMA ${ }^{2}$ \\ ${ }^{1}$ Alliance Protein Laboratories, Thousand Oaks, CA 91360, USA; ${ }^{2}$ Division of Virology, Department of Cellular and \\ Molecular Medicine, Wakayama Medical University Graduate School of Medicine, Wakayama 641-8509, Japan
}

Received March 16, 2010; Accepted June 25, 2010

DOI: $10.3892 / \mathrm{mmr} .2010 .331$

\begin{abstract}
We previously showed that arginine increases the aqueous solubility of the low molecular weight aromatic compounds octyl-gallate (OG) and coumarin. In this study, we focused on acycloguanosine (ACV), an antiherpic agent with moderate aqueous solubility, and examined the effects of arginine on its solubility at a neutral $\mathrm{pH}$. The solubility of ACV increased by approximately 1.9- and 2.6-fold in the presence of 1 and $2 \mathrm{M}$ arginine, respectively, while no solubility changes were observed at an arginine concentration below $0.1 \mathrm{M}$. These results were found to be consistent with observed changes in OG solubility in the presence of arginine. However, ACV and OG exhibited differential binding to bovine serum albumin (BSA): ACV showed no binding to BSA, while OG showed substantial BSA binding. In conclusion, Arginine partially blocked the protein binding of $\mathrm{OG}$.
\end{abstract}

\section{Introduction}

We previously studied the modulation of the solubility of proteins and small molecules by solvents $(1,2)$, and demonstrated that aqueous arginine solution at 0.1-2 $\mathrm{M}$ suppressed protein aggregation $(3,4)$ and increased the solubility of poorly water-soluble small organic compounds $(1,2)$. Acycloguanosine (Acyclovir; ACV) is an antiherpic agent (5) with moderate aqueous solubility. Here, we examined the effects of arginine at a neutral $\mathrm{pH}$ on the solubility of ACV. A combination of $50 \mathrm{mM}$ arginine and glutamate was also tested for its effects on ACV solubility, as it was previously observed to increase the solubility of several proteins (6).

Drug binding to serum proteins often causes the loss of pharmacological activity (7). Since arginine modulates the solubility of both small molecules and proteins (1-4), we speculated that it might also modulate drug binding to proteins. Human serum albumin (HSA) is one of the most

Correspondence to: Dr Tsutomu Arakawa, Alliance Protein Laboratories, 3957 Corte Cancion, Thousand Oaks, CA 91360, USA E-mail: tarakawa2@aol.com

Key words: acycloguanosine, octyl-gallate, arginine, solubility, bovine serum albumin abundant proteins that bind to drug substances (7,8-12). In the present study, bovine serum albumin (BSA) was used as a model protein to test the effect of arginine on ACV binding to protein. While ACV showed no binding to BSA, free octylgallate $(\mathrm{OG})$ concentrations were substantially reduced in the presence of BSA, indicating OG binding to the protein. This binding was reduced in the presence of arginine.

\section{Materials and methods}

ACV was obtained from Sigma and OG from Wako Chemicals. Solubility measurements were carried out as previously described $(1,2)$. Approximately 5-10 mg of ACV were weighed into eppendorf tubes, and $1 \mathrm{ml}$ of test solvents was added. The suspension was incubated at room temperature for 1 day or longer with frequent vortexing, and then centrifuged to separate the supernatant. No effect of longer incubation was observed. The supernatant was appropriately diluted with water for absorbance measurements, and the concentration of ACV was spectrophoretically determined at $252 \mathrm{~nm}$. All the test solvents were prepared in $50 \mathrm{mM}$ Na phosphate, $\mathrm{pH}$ 7.0. This strong buffer was required to minimize $\mathrm{pH}$ changes upon the dissolution of basic ACV. The $\mathrm{pH}$ after dissolution was confirmed to be unchanged. The solubility of OG was similarly determined (1).

The binding of ACV to BSA was determined using ultrafiltration. Stock solutions of $0.5 \mathrm{mg} / \mathrm{ml} \mathrm{ACV}$ and $100 \mathrm{mg} / \mathrm{ml}$ BSA were prepared in $50 \mathrm{mM}$ phosphate, $\mathrm{pH}$ 7.0. This ACV concentration was below the solubility $(\sim 1.5 \mathrm{mg} / \mathrm{ml})$ of the buffer. Solutions were prepared at ACV to BSA ratios of 50:1 and 1:1. After a 1-day incubation at room temperature, the solution was filtered using centricon-10. The ACV concentration in the filtrate was determined by the absorbance at $252 \mathrm{~nm}$ after appropriate dilution in water. As a control, ACV was also mixed with the test solvents without the addition of BSA, and used to calculate the recovery of ACV in the filtrate.

A similar process was applied to prepare the OG solutions. However, as OG is poorly soluble in water or buffer, a stock OG solution was prepared containing $0.15 \mathrm{mg} / \mathrm{ml} \mathrm{OG}$ in $25 \%$ ethanol, and was combined with the stock BSA solution in $50 \mathrm{mM}$ phosphate, $\mathrm{pH}$ 7.0. The OG to BSA ratios of the solutions were 7:1 and 0.7:1. The OG concentration in the filtrate was spectrophotometrically determined by the absorbance at $272 \mathrm{~nm}$ after appropriate dilution in water. 
Table I. Acycloguanosine solubility in $50 \mathrm{mM}$ Na phosphate, pH 7.0.

Solvent

$50 \mathrm{mM}$ Na phosphate

$50 \mathrm{mM}$ arginine

$0.1 \mathrm{M}$ arginine

$0.5 \mathrm{M}$ arginine

$1 \mathrm{M}$ arginine

$2 \mathrm{M}$ arginine

$50 \mathrm{mM}$ Na glutamate

$1 \mathrm{M}$ Na glutamate

$2 \mathrm{M}$ Na glutamate

Solubility of acycloguanosine in $50 \mathrm{mM}$ Na phosphate, $\mathrm{pH} 7.0$, is $\sim 1.5 \mathrm{mg} / \mathrm{ml}$.

The antiviral activity of OG was measured using herpes simplex virus type-1 (HSV-1) and HEp-2 cells, as described previously (13). Briefly, monolayered HEp-2 cells in 35-mm dishes were infected with the virus at an indicated multiplicity of infection (MOI). The infected cells were further incubated at $37^{\circ} \mathrm{C}$ for the indicated periods in the serum-free MEM containing $0.1 \%$ BSA and the indicated concentrations of the respective reagent. At the end of infection, the amounts of total progeny virus in the infected cultures were determined after two or three cycles of freezing and thawing of the infected cells along with the culture media as described previously (14). Cell culture was carried out as a function of OG concentration $(0-80 \mu \mathrm{g} / \mathrm{ml})$ in the presence of 1 and $40 \mathrm{mg} / \mathrm{ml} \mathrm{BSA}$.

\section{Results and Discussion}

First, the solubility of ACV in $50 \mathrm{mM}$ phosphate, $\mathrm{pH}$ 7.0, was determined by incubating 3-5 $\mathrm{mg}$ powder in $1 \mathrm{ml}$ of the buffer. The absorbance of $1 \mathrm{mg} / \mathrm{ml} \mathrm{ACV}$ in this buffer was predetermined to be 55 at $252 \mathrm{~nm}$ for a $1 \mathrm{~cm}$ path-length. Using this value, the ACV solubility was $\sim 1.5 \mathrm{mg} / \mathrm{ml}$ in the buffer. The solubility of ACV in the test solvents was expressed as the solubility ratio. As shown in Table I, arginine at higher concentrations $(>0.5 \mathrm{M})$ greatly increased the solubility of ACV. The solubility ratio is plotted in Fig. 1 as a function of additive concentration. Arginine had little effect on ACV solubility at 0.05 and $0.1 \mathrm{M}$, but greatly increased solubility by 1.6-, 1.9- and 2.6-fold at $0.5,1$ and $2 \mathrm{M}$, respectively. Na glutamate significantly decreased solubility, with an approximately halved solubility ratio with $2 \mathrm{M}$ Na glutamate solution (Table I and Fig. 1). Of note, no data were obtained with concentrations of 0.1 and $0.5 \mathrm{M}$ Na glutamate. This is consistent with the known salting-out properties of $\mathrm{Na}$ glutamate at high concentrations, such as those used here $(4,15,16)$.

It has been shown that a combination of $50 \mathrm{mM}$ $\mathrm{Na}$ glutamate and $50 \mathrm{mM}$ arginine at a neutral $\mathrm{pH}$ increases the solubility of several proteins (6). Here, we examined its effects on ACV. Table II shows that $50 \mathrm{mM}$ Na glutamate alone did not increase the solubility of ACV; rather, it slightly decreased

Table II. Acycloguanosine solubility in $50 \mathrm{mM}$ Na phosphate, pH 7.0.

Solvent

Solubility ratio

$50 \mathrm{mM}$ Na phosphate

$1 \mathrm{M}$ arginine

1

$1 \mathrm{M}$ Na glutamate

$1 \mathrm{M}$ arginine/1 $\mathrm{M}$ glutamate

$50 \mathrm{M}$ arginine

$50 \mathrm{mM}$ Na glutamate

$50 \mathrm{mM}$ arginine $/ 50 \mathrm{mM}$ glutamate

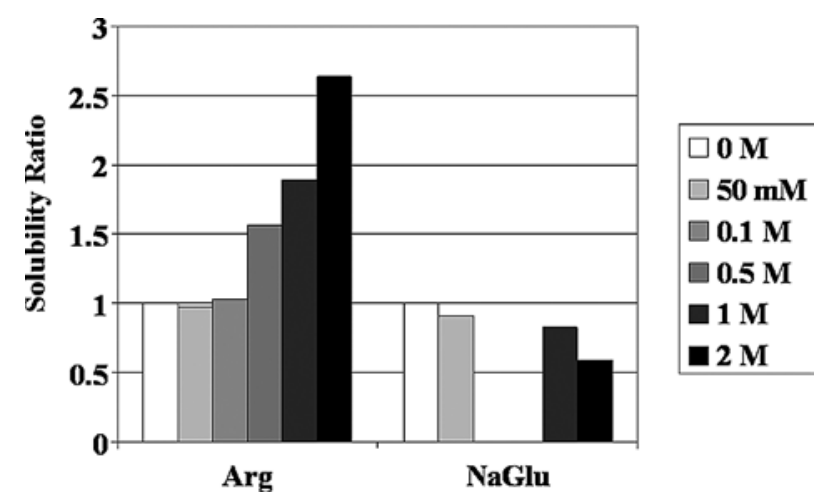

Figure 1. Solubility ratio of $\mathrm{ACV}$ as a function of arginine (Arg) and $\mathrm{Na}$ glutamate $(\mathrm{NaGlu})$ concentration. No data in 0.1 and $0.5 \mathrm{M}$ Na glutamate.

it by 0.91 -fold. A $50-\mathrm{mM}$ concentration of arginine similarly had no effect. As shown in Table I, 50 and $100 \mathrm{mM}$ arginine were essentially ineffective, while $0.5 \mathrm{M}$ arginine resulted in a significant increase in ACV solubility. As $50 \mathrm{mM}$ arginine and $\mathrm{Na}$ glutamate individually do not increase the solubility of $\mathrm{ACV}$, it was expected that a combination of these would have no impact on the ACV solubility. As expected, solubility in the presence of the combination of reagents at $50 \mathrm{mM}$ was identical, within experimental error limits to the value in the absence of these reagents, with a mean \pm SD of $0.97 \pm 0.04$. The combination of $1 \mathrm{M}$ arginine, which increased solubility by 1.89 -fold, and $1 \mathrm{M} \mathrm{Na}$ glutamate, which decreased it by 0.83 -fold, was also tested. The resulting solubility increase was approximately mid-way between that of the individual solvents: a 1.7-fold increase with the combination vs. a 1.89fold increase with $1 \mathrm{M}$ arginine alone, reflecting the slight salting-out effect of $1 \mathrm{M} \mathrm{Na}$ glutamate. It thus appears that these two reagents affect ACV solubility independently.

Previously, we determined the solubility of OG in aqueous arginine solution (1). The results are replotted in Fig. 2 in comparison to those for ACV solubility. The aqueous solubility of OG is much lower $(\sim 0.07 \mathrm{mg} / \mathrm{ml})$ than that of ACV $(\sim 1.5 \mathrm{mg} / \mathrm{ml})$. The effects of arginine appear to be slightly weaker on ACV than on OG: $1 \mathrm{M}$ arginine increased OG solubility by $\sim 2$.2-fold, and ACV solubility by $\sim 1.9$-fold. This may reflect the aqueous solubility of the compounds. The higher solubility of ACV indicates that it is more solvated by water than $\mathrm{OG}$, and the favorable interaction of arginine with 


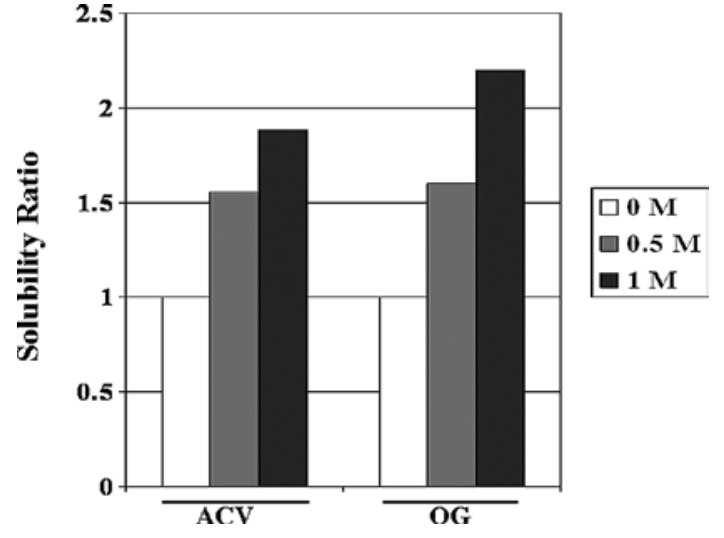

Figure 2. Solubility ratio of ACV and $\mathrm{OG}$ in the presence of arginine.

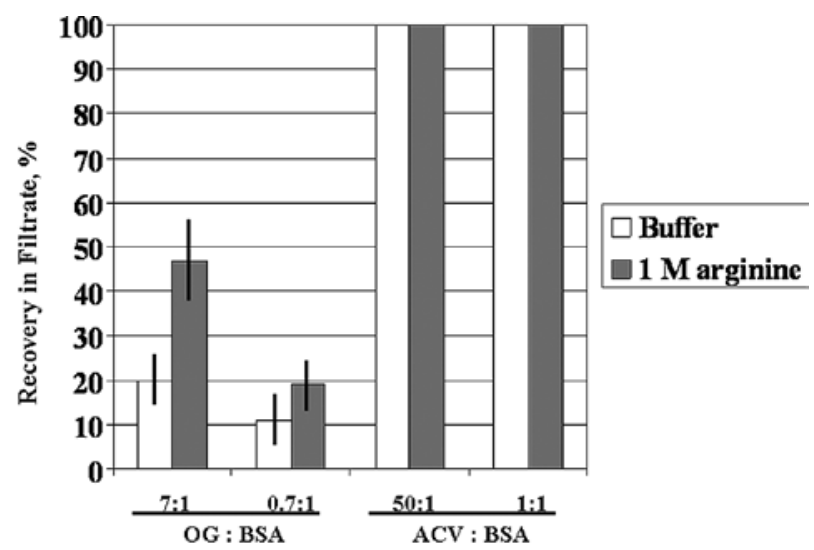

\begin{tabular}{|c|c|c|}
\hline Molar Ratio & Octyl-gallate (OG) or Acycloguanosine (ACV) & BSA \\
\hline $7: 1$ & OG, $0.03 \mathrm{mg} / \mathrm{ml}$ & $1 \mathrm{mg} / \mathrm{ml}$ \\
\hline $0.7: 1$ & OG, $0.03 \mathrm{mg} / \mathrm{ml}$ & $10 \mathrm{mg} / \mathrm{ml}$ \\
\hline $50: 1$ & ACV, $0.25 \mathrm{mg} / \mathrm{ml}$ & $1 \mathrm{mg} / \mathrm{ml}$ \\
\hline $1: 1$ & ACV, $0.05 \mathrm{mg} / \mathrm{ml}$ & $10 \mathrm{mg} / \mathrm{ml}$ \\
\hline
\end{tabular}

Figure 3. Binding of $\mathrm{OG}$ and $\mathrm{ACV}$ to BSA. The composition of each mixture is given in the table.

ACV contributes less to the solvation energy of ACV than OG in aqueous arginine solution.

The observed increase in ACV and $\mathrm{OG}$ solubility by arginine indicates a favorable interaction between these compounds and arginine, as has previously been observed for proteins and amino acids (17-19). To determine the effect of this favorable interaction on the binding of these compounds to a protein, in this case $\mathrm{BSA}, \mathrm{OG}$ or $\mathrm{ACV}$ were mixed with BSA at various molar ratios, as shown in Fig. 3, in the absence and presence of $1 \mathrm{M}$ arginine. A control reference solution, without BSA, was used to determine the $100 \%$ recovery. When $0.03 \mathrm{mg} / \mathrm{ml} \mathrm{OG}$ was mixed with $1 \mathrm{mg} / \mathrm{ml} \mathrm{BSA}$ at a molar ratio of $7: 1$, the concentration of free OG was only $20 \%$ in the presence of BSA, i.e., $0.024 \mathrm{mg}$ OG bound to $1 \mathrm{mg}$ BSA (Fig. 4). When the BSA concentration was increased to $10 \mathrm{mg} /$ $\mathrm{ml}$ at a molar ratio of $0.7: 1$, binding was further increased: only $\sim 10 \%$ of the initial OG concentration was detected in the filtrate. Thus, $\sim 90 \%$ of the OG was bound by BSA. The addition of $1 \mathrm{M}$ arginine reduced this binding. In both molar ratios, the free OG concentration was increased by $\sim 2$-fold, meaning that less OG was bound by BSA in the presence of arginine.

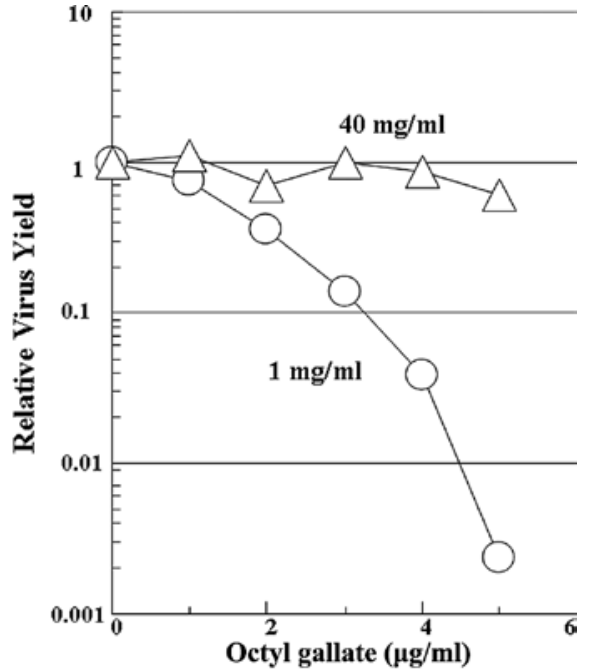

Figure 4. Antiviral activity of OG in the presence of 1 and $40 \mathrm{mg} / \mathrm{ml} \mathrm{BSA.}$

Notably, although multiple arginine residues are involved in the binding of drugs to HSA $(20,21)$, these arginine residues may not be the binding sites of OG.

By contrast, ACV showed no apparent binding to BSA, and the concentration of ACV observed in the filtrate was identical in the absence or presence of BSA, whether $1 \mathrm{M}$ arginine was included or not. Thus, no loss of ACV was observed due to binding to BSA. ACV differs from OG in its binding to BSA since the aqueous solubility of ACV $(\sim 1.5 \mathrm{mg} /$ $\mathrm{ml})$ is $\sim 20$-fold higher than that of OG $(\sim 0.07 \mathrm{mg} / \mathrm{ml})$. This means that aqueous buffer solution is already a better solvent for ACV; in other words, ACV has a higher affinity for water than OG. Thus, the poorly water-soluble OG has a higher affinity for BSA.

The binding of drug substances to proteins is a major obstacle to their bioavailability. The observed binding of OG to BSA appears to correlate with the inhibition of antiviral activity of $\mathrm{OG}$ in BSA. The antiviral activity of $\mathrm{OG}$ was tested in the presence of 1 and $40 \mathrm{mg} / \mathrm{ml} \mathrm{BSA.} \mathrm{The}$ virus yield is plotted against OG concentration in Fig. 4. A dose-dependent decrease in virus yield was observed in the presence of $1 \mathrm{mg} / \mathrm{ml}$ BSA. By contrast, virus yield was barely affected by increasing OG concentrations. For example, $5 \mu \mathrm{g} /$ $\mathrm{ml} \mathrm{OG}$ led to 0.002 virus yield in the presence of $1 \mathrm{mg} / \mathrm{ml}$ BSA, but only 0.5 in the presence of $40 \mathrm{mg} / \mathrm{ml} \mathrm{BSA.} \mathrm{The}$ molar ratio of $5 \mu \mathrm{g} / \mathrm{ml} \mathrm{OG}$ to $40 \mathrm{mg} / \mathrm{ml} \mathrm{BSA} \mathrm{corresponds} \mathrm{to}$ 0.38:1 (OG:BSA), which is slightly lower than the ratio used for the binding experiment described above. Approximately $90 \%$ OG was bound by BSA at a molar ratio of $0.7: 1$; hence, a nearly complete suppression of antiviral activity at a molar ratio of $0.38: 1$ appears to be consistent with the binding data. A further increase in OG concentration, to $80 \mu \mathrm{g} / \mathrm{ml}$, resulted in 0.1 virus yield, even in the presence of $40 \mathrm{mg} / \mathrm{ml} \mathrm{BSA}$. This corresponds to the OG:BSA ratio of $6: 1$; i.e., the excess of $\mathrm{OG}$ over BSA concentration. Unfortunately, the same assay cannot be performed in the presence of $1 \mathrm{M}$ arginine, which kills the host HEp-2 cells used for the assay.

The problem of drug binding to proteins is particularly severe for compounds with poor water-solubility, such as OG (7). Arginine at least partially inhibits such binding. As is the 
case for the antiviral assay described above, arginine is toxic to the cells even in an in vitro cell culture, and therefore cannot be used systemically. However, there may be a possibility of topical applications, where drugs are applied to the mucosal surface and secreted proteins bind the drugs. Arginine even at high concentrations is safe on the mucosal surface (unpublished observation).

\section{References}

1. Arakawa T, Kita Y and Koyama AH: Solubility enhancement of gluten and organic compounds by arginine. Int $\mathrm{J}$ Pharm 355: 220-223, 2008

2. Hirano A, Arakawa $\mathrm{T}$ and Shiraki K: Arginine increases the solubility of coumarin: comparison with salting-in and salting-out additives. J Biochem 144: 363-369, 2008.

3. Arakawa $\mathrm{T}$ and Tsumoto $\mathrm{K}$ : The effects of arginine on refolding of aggregated proteins: not facilitate refolding, but suppress aggregation. Biochem Biophys Res Commun 304: 148-152, 2003.

4. Arakawa T, Kita Y, Tsumoto K, Ejima D and Fukada H: Aggregation suppression of proteins by arginine during thermal unfolding. Protein Pept Lett 13: 921-927, 2006.

5. Coen DM and Richman DD: Antiviral agents. In: Fields Virology. 5th edition. Knipe DM, Howley PM, Griffin DE, Ramb RA, Straus SE, Martin MA and Roizman B (eds). Lippincott-Raven, New York, pp447-485, 2007.

6. Golovanov AP, Hautbergue GM, Wilson SA and Lian LY: Simple method for improving protein solubility and long-term stability. J Am Chem Soc 126: 8933-8939, 2004.

7. Otagiri M: Study on binding of drug to serum proteins. Yakugaku Zasshi 129: 413-425, 2009.

8. Sudlow G, Birkett DJ and Wadem DN: Spectroscopic techniques in the study of protein binding. A fluorescence technique for the evaluation of the albumin binding and displacement of warfarin and warfarin-alcohol. Clin Exp Pharmacol Physiol 2: 129-140, 1975.

9. Sudlow G, Birkett DJ and Wadem DN: Further characterization of specific drug binding sites on human serum albumin. Mol Pharmacol 12: 1052-1061, 1976.

10. Yamasaki K, Maruyama T, Kragh-Hansen U and Otagiri M: Characterization of site I on human serum albumin: concept about the structure of a drug binding site. Biochim Biophys Acta 1295: 147-157, 1996
11. Maruyama T, Lin CC, Yamasaki K, Miyoshi T, Imai T, Yamasaki $\mathrm{M}$ and Otagiri $\mathrm{M}$ : Binding of suprofen to human serum albumin. Role of the suprofen carboxyl group. Biochem Pharmacol 45: 1017-1026, 1993.

12. Kragh-Hansen U, Watanabe $H$, Nakajou K, Iwao $Y$ and Otagiri M: Chain length-dependent binding of fatty acid anions to human serum albumin studied by site-directed mutagenesis. J Mol Biol 363: 702-712, 2006.

13. Uozaki M, Yamasaki H, Katsuyama Y, Higuchi M, Higuchi T and Koyama AH: Antiviral effect of octyl gallate against DNA and RNA viruses. Antiviral Res 73: 85-91, 2007.

14. Koyama $\mathrm{AH}$ and Uchida $\mathrm{T}$ : Inhibition by Brefeldin $\mathrm{A}$ of the development of nucleocapsids in herpes simplex virus type 1-infected Vero cells. Arch Virol 135: 305-317, 1994.

15. Arakawa T and Timasheff SN: The mechanism of action of $\mathrm{Na}$ glutamate, lysine $\mathrm{HCl}$, and piperazine-N,N'-bis(2-ethanesulfonic acid) in the stabilization of tubulin and microtubule formation. $\mathrm{J}$ Biol Chem 259: 4979-4986, 1984.

16. Arakawa T, Kita Y and Narhi LO: Hydrophobic interaction chromatography in alkaline pH. Anal Biochem 182: 266-270, 1989.

17. Kita Y, Arakawa T, Lin TY and Timasheff SN: Contribution of the surface free energy perturbation to protein-solvent interaction. Biochemistry 33: 15178-15189, 1994.

18. Arakawa T, Ejima D, Tsumoto K, Obeyama N, Tanaka Y, Kita Y and Timasheff SN: Suppression of protein interactions by arginine: a proposed mechanism of the arginine effects. Biophys Chem 127: 1-8, 2007.

19. Das U, Hariprasad G, Ethayathulla AS, Manral P, Das TK, Pasha S, Mann A, Ganguli M, Verma AK, Bhat $R$, Chandrayan SK, Ahmed S, Sharma S, Kaur P, Singh TP and Srinivasan A: Inhibition of protein aggregation: supramolecular assemblies of arginine hold the key. PLoS ONE 14: 1-9, 2007.

20. Watanabe $H$, Tanase $S$, Nakajou $K$, Maruyama $T$, Kragh-Hansen $U$ and Otagiri M: Role of arg-410 and tyr-411 in human serum albumin for ligand binding and esterase-like activity. Biochem J 349: 813-819, 2000.

21. Watanabe H, Kragh-Hansen U, Tanase S, Nakajou K, Mitarai M, Iwao Y, Maruyama T and Otagiri M: Conformational stability and warfarin-binding properties of human serum albumin studied by recombinant mutants. Biochem J 357: 269-274, 2001. 